\title{
Arabic Medicine
}

\section{Omar M Amin*}

Parasitology Center, Scottsdale, Arizona

*Corresponding Author: Omar M Amin, Parasitology Center, Scottsdale, Arizona.

Received: July 12, 2019; Published: September 26, 2019

DOI: 10.31080/ASMI.2019.02.0384

\begin{abstract}
The earliest records of Arabic medicine date to the pre-Islamic era during the 6th century especially in Jundishahpur in Persia after the collapse of the western Roman Empire in the 5th century. Contributions of Arabic medicine flourished in Baghdad, during the Abbasid dynasty, Cairo, Toledo, and Cordoba and from there to France and Western Europe. Islamic physicians first familiarized themselves with the works of Hippocrates, Galen and other Greek writers as well as the knowledge of India, China, Persia and Byzantium. Famous Arab physicians in internal and clinical medicine included Ar-Razi (826 - 925), Al Tabri (960 - 1004), Al Majusi (-994), Bin Butlan (-1068), among many others. The early medical work was usually combined with treaties on philosophy, mathematics, physics, treatments, and public health. Other branches of medicine included surgery (Az-Zahrawi, 940 - 1013), neurology (Ibn Sina, Ar Razi, Ibn Rushd), other organ systems (Mansur Ibn Ilyas, 14 $4^{\text {th }}$ century), herbology (Al Amashati and Al Attar), Ophthalmology (Ibn Ishaq and Hubaysh, Al-Mawsili, Abu Al-Mahasin, Bin Yusuf), pharmacology (bin Sahl, Ar-Razi, Al-Biruni). Considerable developments of hospitals and medical education took place beginning in the $10^{\text {th }}$ century upkeeping the tradition of teaching hospitals. Veterinary medicine witnessed its fastest development begining in 860 (Akhi Hizam, Al-Jahiz, Al-Baytar, Ad-Damiri).

Contemporary Europeans regard Ibn Sina and Ar-Razi as the greatest authorities on medical matters with their portraits exhibited in the Paris School of Medicine next to Hippocrates and Galen in Dante's The Inferno. Writings of more than 400 Arab authors deeply influenced the rebirth of European Science. They laid down the foundation of hospitals, drug trials, clinical investigation, surgery, public and dental health, ophthalmology, diet, hygiene, quarantine and infection theory that are still largely valid and in use today. Keywords: Arabic Medicine; Contributions; History; Rebirth of European Sciences; 400 Physicians; Contemporary Use
\end{abstract}
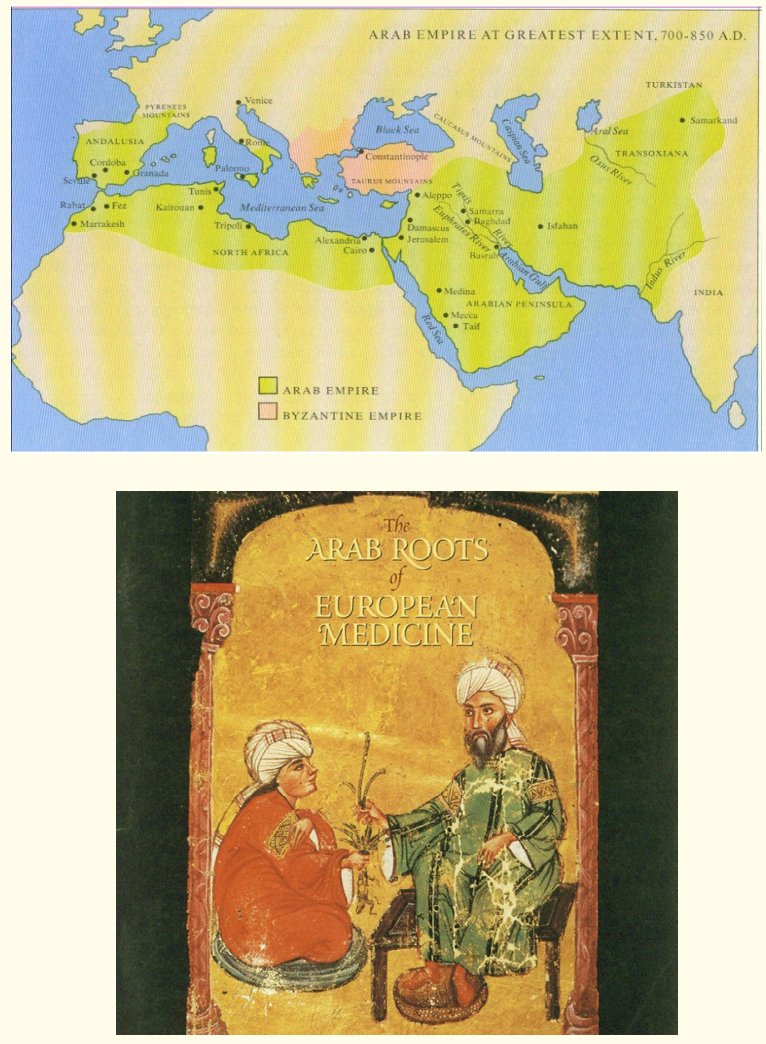

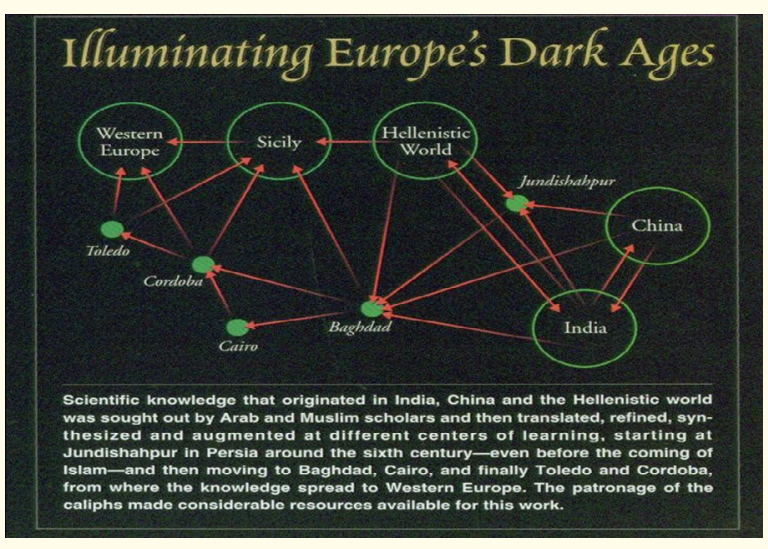

Figure 1

The beginnings of Arabic medicine

The earliest records date to the pre-Islamic era during the 6th century especially in Jundishahpur in Persia. Increasing contributions followed and flourished in Baghdad, during the Abbasid dynasty, Cairo, Toledo and Cordoba and from there to France and Western Europe.

The manuscript of IBN Algazzar of Qairuwan, Andalusia on medicine and philosophy (right). 


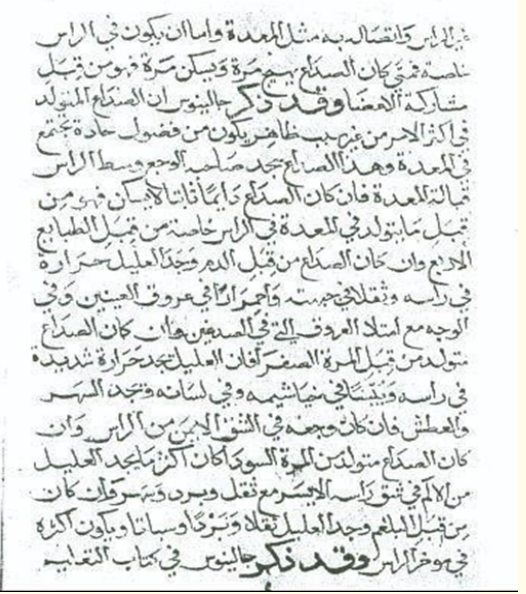

Figure 2

Emergence and evolution

- After the collapse of the Western Roman Empire in the $5^{\text {th }}$ century, Europe lost touch with its intellectual heritage.

- The center of Europe's new world view became the church. Monastic orders ran "hospitals" to take seriously ill people whose sickness or recovery was subject to the will of God. Every malady had a patron Saint. Study of disease and treatment was neglected. In the 7th century, the Catholic church banned surgery by monks as dangerous to their souls.

- At roughly the same time, another civilization was rising in the east. The Arabs rapidly melded the various cultures of the Islamic domain and Arabic became the universal language.

- After Plato's Academy was closed in 527, scholars, found refuge at the University of Jundishahpur, the old Sassanid capital of Persia which became part of the Islamic world in 636. The Arab rulers supported the medical school at Jundishahpur which became the greatest center of medical teaching in the Islamic world for the next 200 years.

Major contributions to assimilation of medical knowledge

Islamic physicians first familiarized themselves with the works of Hippocrates, Galen and other Greek writers as well as the knowledge of India, China, Persia and Byzantium. The Abbasid caliphs Harun al-Rashid (786 - 809) (who established the 1st the first hospital in the modern sense in Baghdad in 805) and his son, $\mathrm{Al}$ Ma'mun (813 - 833) established a translation bureau in Baghdad, Bayt al-Hikmah (house of wisdom) and sent embassies to collect Greek scientific works in the Byzantine Empire. This ushered the major era in Islamic medicine.

\section{Major works of translation}

The most important translators was Hunayan ibn Ishaq al- Ibadi (807 - 873), who was reputed to have been paid for his manuscripts by an equal weight of gold. He and his team of translators rendered the entire body of Greek medical texts of Galen, Paul of Aegin, Oribasius, Hippocrates and the Materia Medica of Dioscorides) into Arabic by the end of the $9^{\text {th }}$ century. The cover of Galen's Book of Antidotes (right).

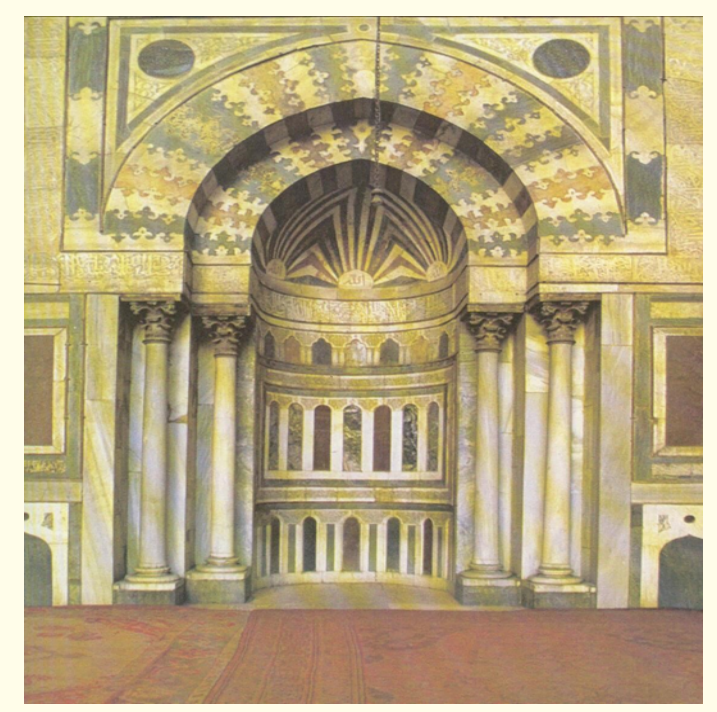

Figure 3

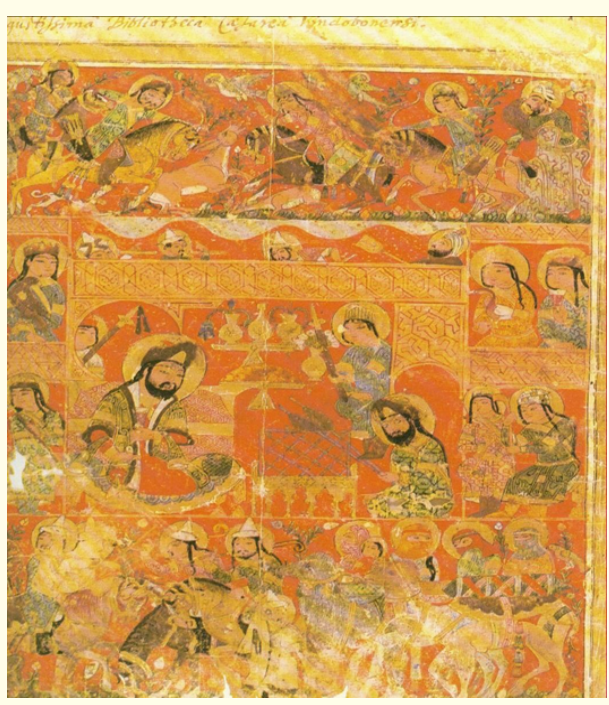

Figure 4

Internal and clinical medicine

- Abu Bakr Mohamed bin Zakariya ar-RaZi (826925).

- The greatest clinician, pathologist, medical educator and philosopher of his time.

- Honored with this stained glass window in the Princeton Univ. Chapel celebrating his contributions to medicine.

\section{Ar-RaZi (known as Rhazes)}

- Assumed a career in medicine at 40 in Baghdad after being a musician, mathematician and alchemist. Authored 237 books; half in medicine. 
- Al Kitab al Mansuri: on medical theories, definitions, diet, drugs, wellness, mother child care, skin diseases, mouth hygiene, climatology, epidemiology and toxicology.

- $\quad$ Al Tibb ar Ruhani: on psychiatric medicine and relationship between psyche and soma.

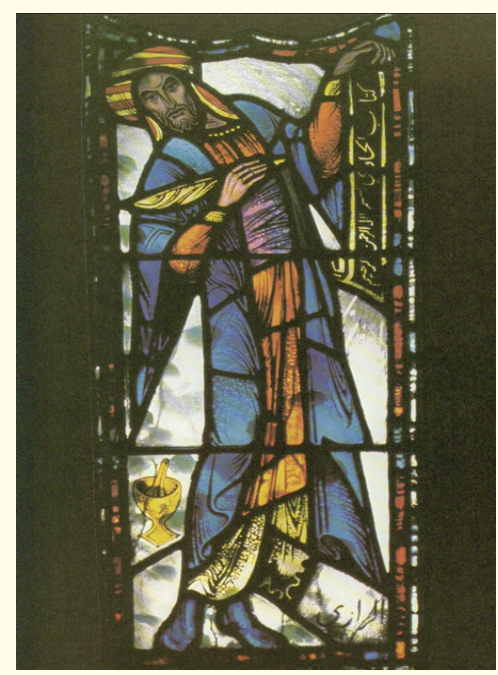

Figure 5

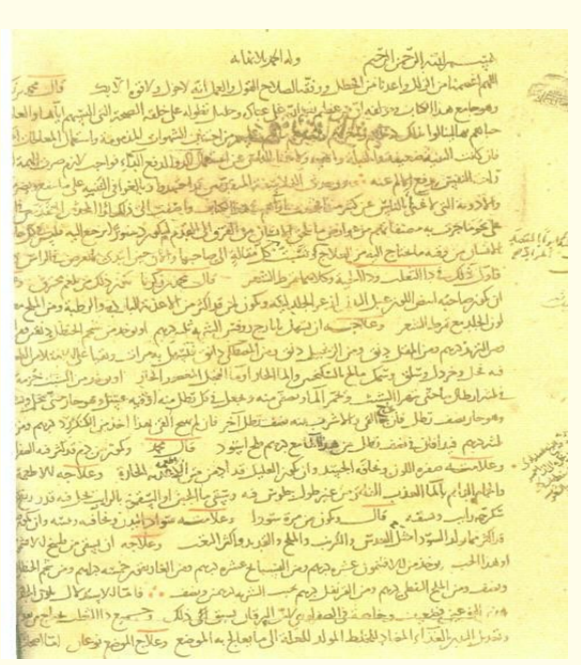

Figure 6

Other contributions by Ar-RaZi

Advocated experimental approach and testing and the reliance on observation rather than on received authority; crusaded against quacks

- Al Hawi fi at-Tibb (25 books): psychic therapy with detailed case histories and diagnoses.

- Al Kannash Al Fakher: On diseases from head to toe, diet and medical therapy.

- Al-Judari wa al Hasba: On the description and differential diagnosis of measles and smallpox
One hour recovery: on all the diseases that can be cured within one hour. The Diseases of Children: Pediatrics. From Al Kannash Al Fakher (right and previous).

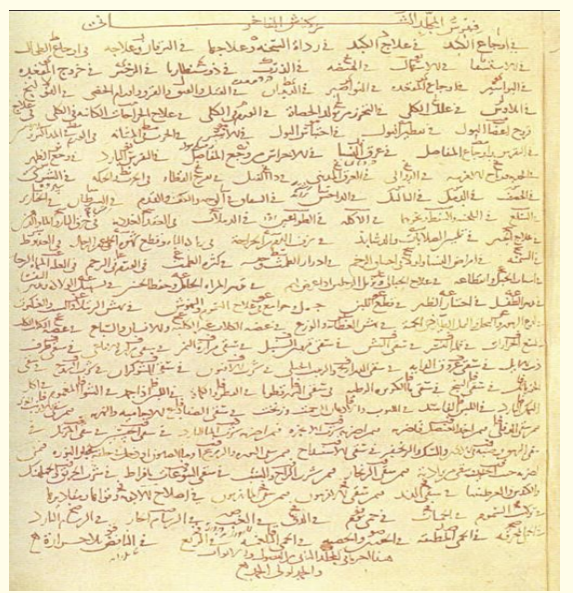

Figure 7

The Al Tabris (not related)

Abu Al Hassan Ali bin Sahl bin Rubn Al Tabri Teacher of Ar-RaZi.

His most important medical works "Paradise of Wisdom" in 848. In 7 books and 360 chapters.

1. Nature of biological organisms and physical things.

2. Embryology and psyche.

3. Malnutrition and diet.

4. Public health and causation.

5. Qualities of tastes, plants and minerals

6. Vegetarian and animal diets.

7. Countries, waters, winds, seasons and atmosphere.

Abu Al Hassan Ahmed bin Mohamed Al Tabri (960-1004) "Hippocratic renditions" (10 theses was his most significant work.

1. The seasons (50 chapters).

2. Skin (face) diseases (35 chapters).

3. Internal medicine (34 chapters).

4. Ophthalmology (54 chapters).

5. Ear, nose and throat (33 chapters).

6. Dental and mouth diseases (58 chapters).

7. Dermatology (60 chapters).

8. Chest and lung diseases (33 chapters).

9. Intestinal health (52 chapters).

10. Liver/spleen diseases ( 49 chapters).

\section{ALI bin al Abbas al Majusi (Died 994)}

Al Majusi is ar-RaZi's natural worthy successor. In his Liber regius (al-Maliki), he made important original observations on medical theories and diagnosis, including new concepts re environmental impact on health, the nutritional value of diets and action of drugs 
in a new system of codifying, classifying and theorizing detailed observations. Table of contents of "The Complete Medical Science" (right).

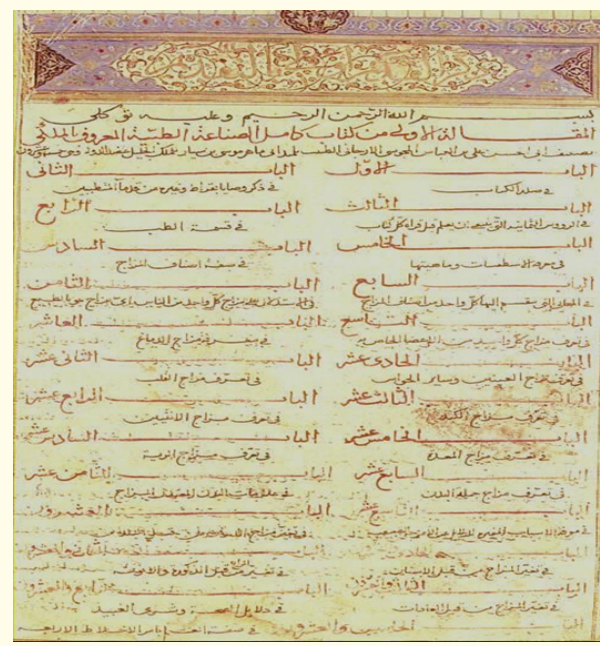

Figure 8

\section{Al-Mukhtar bin Abdun bin Butlan (Died 1068)}

Bin Bultan, a Baghdad-based physician- philosopher was a reformer in matters of public health and clean environment. His Taqwim as-Sihhah on the preservation and restoration of good health won him great prestige and was translated to Latin and published repeatedly. He elaborated on 6 principles to be kept in equilibrium: clean air, moderate diet and drink, rest and work, wakefulness and slumber, evacuation, and emotions. A 1231 copy of Taqwim as-Sihhah.

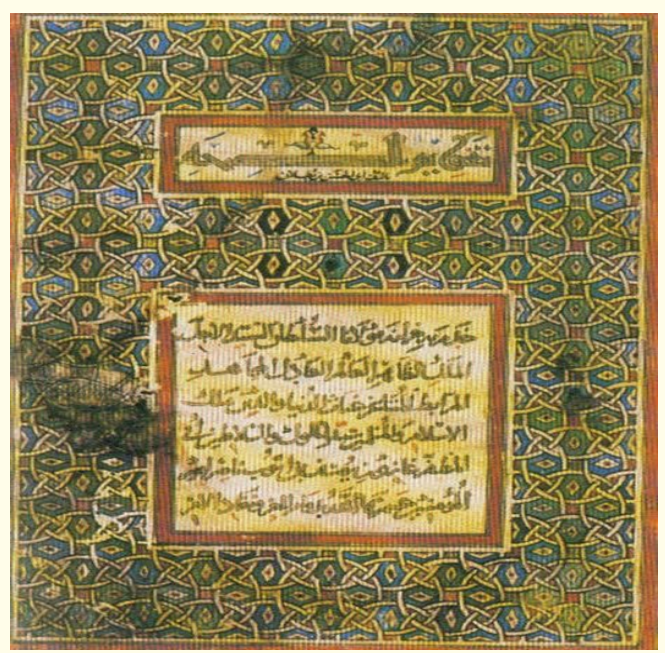

Figure 9

Major medical contributions of other physicians

- Ibn al Jazzar (died 984) of Kairouwan, Tunisia: books on management and care of children from birth, midwives, therapeutics, diet and internal medicine.
- Arib bin Said of Cordoba: pediatrics, gynecology, embryology.

- Az-Zahrawi (936 - 1013) (student of bin Said and first Arab surgeon): pharmacy, medical botany, internal and clinical medicine and especially surgery.

- Ibn Wafied (died 1068) of Andalusia: clinical med. and therapeutics.

- Ibn Zuhr (died 1162) (=Avenzoar): in at-Taysir, first description of mediastinal abscesses and wet and dry pericarditis. Bedside clinical observation, medical experimentation, pathology.

- Rabbi Musa bin Maymun (1134 - 1204): internal medicine, health and environment, materia medica, therapeutics; in Arabic and Hebrew. Abu al-Qasim Khalaf bin 'Abbas az-Zahrawi (albucasis) (940 - 1013)

- Practiced medicine and surgery until his death in azZahra, near Cordoba, in Ummayad Andalusia.

- 'At-Tasrif': a voluminous compendium of 30 treatises of medical data including his own experience over 50 years of practice. It deals with anatomy and physiology, doctor patient relationship, observational studies, diagnosis and treatment, causes and symptoms, clinical and mental health, preparation of drugs, weights and measurements, Materia Medica, drug substitution, care of the aged, ethical norms, surgical procedures and instruments (right).

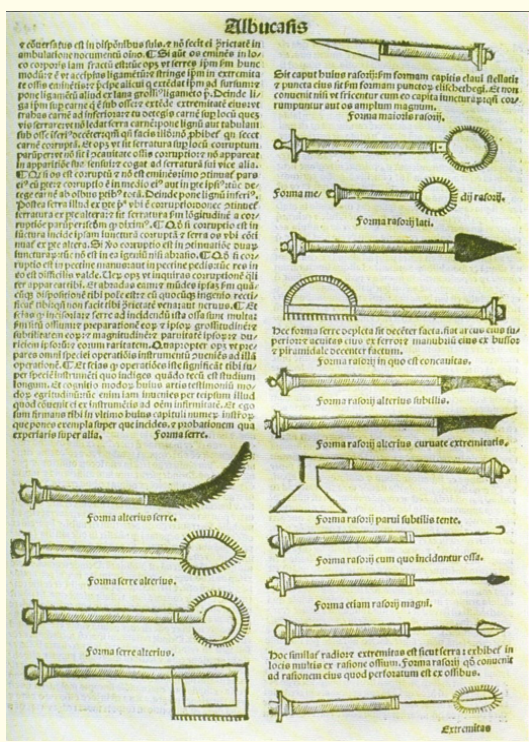

Figure 10

\section{Az-Zahrawi}

- Az-Zahrawi's last treatise dealt with surgery and included cautery, treatment of wounds, extraction of arrows, oral hygiene and the setting of bones in simple and compound frac- 
tures. He used antiseptics for the treatment of wounds and skin injuries, made sutures from animal skin and developed techniques to widen urinary passages. He designed over 200 surgical instruments.

- Az-Zahrawi's dental instruments including a tongue depressor and tooth extractors.

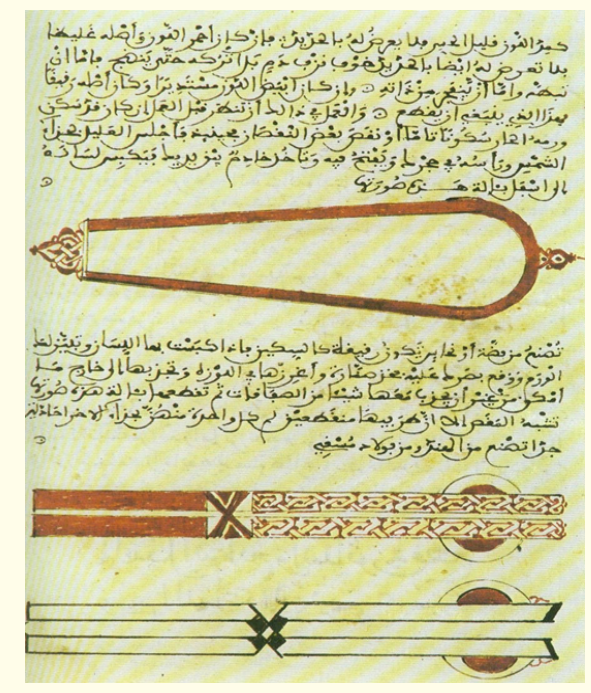

Figure 11

\section{Az-Zahrawi' non-surgical work}

Az-Zarrawi wrote many medical books including The Properties of Various Products. This page discusses the use and preparation of absinthe

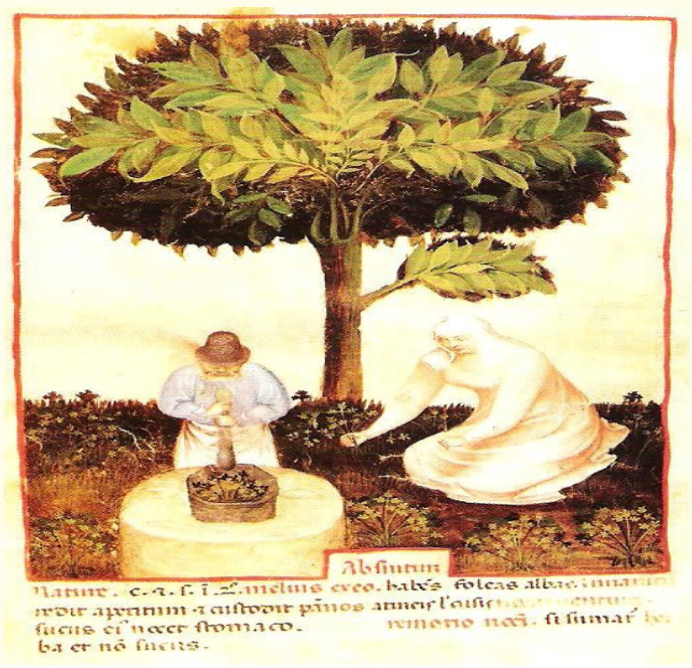

Figure 12

The nervous system

This woodcut from a book about the nervous system, published in Venice, Italy in 1495, shows shelved reference volumes by the Muslem physicians Avicenna (Ibn Sina), Rhazes (Ar-Razi) and Ibn Rushd, along side works by Aristotle and Hippocrates.

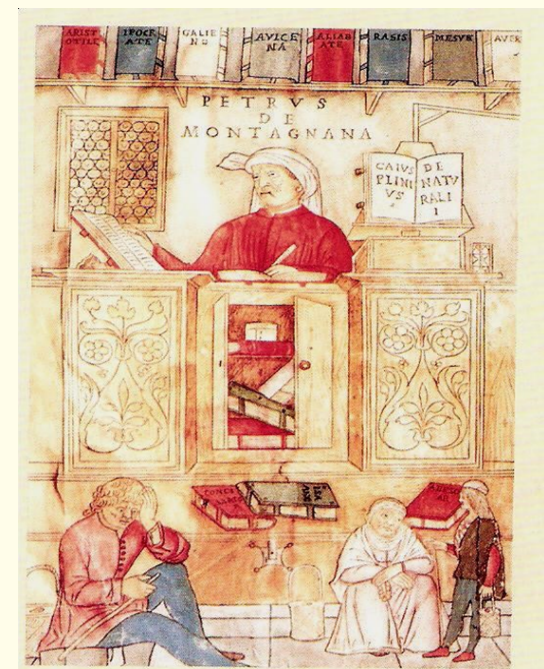

Figure 13

\section{Other organ systems}

Mansour Ibn Ilyas's $14^{\text {th }}$ century work on anatomy contained illustrated chapters on five systems of the body: skeletal, nervous, muscular and circulatory (veins and arteries). This page depicts the arteries with the internal organs shown in watercolor.

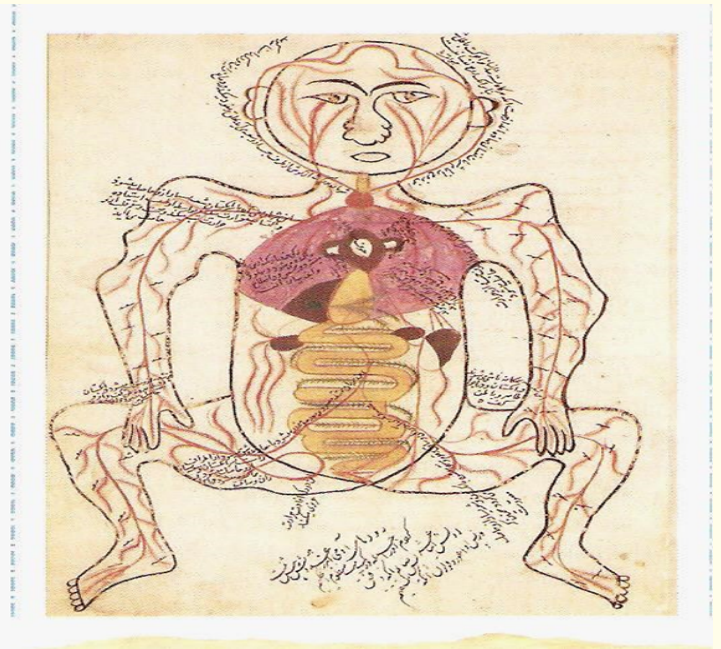

Figure 14

Medical knowledge was often reviewed by a considerable number of physicians. Two famous works by al Amshati (Health Plants; left) and al Attar (Procedures of Practice and Rules for the Affluent; right).

Abu Al Walid Mohamed ibn Rushd (Averroes) (1125 - 1198) A doctor, philosopher and Renaissance man.

A man can be adopted by a civilization other than his own and can there become a symbol of something very different from that which he signifies to his own civilization. 


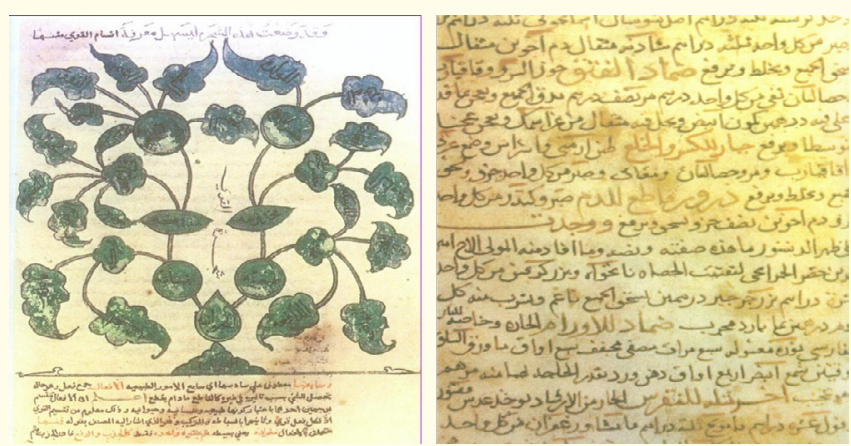

Figure 15

The medieval Arab and European worlds knew him by two names. The Arab world today remembers him as the medical pioneer. In the West, he is esteemed for his philosophy.

A statue of ibn Rushd honoring him in his home town Cordoba.

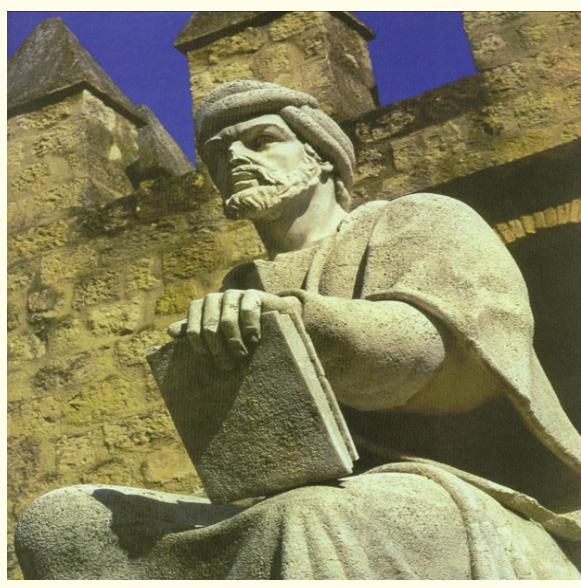

Figure 16

Ibn Rushd's major works

- "Al-Kulliyat" on general medical theories and precepts (translated into Latin in 1255 and printed independently in Venice in 1482).

- On Ibn Sina's famous medical poem

- "Canticum de medicina."

- $\quad$ On astronomy in Marrakech (1153).

- “Compendium on medical knowledge" (1165)

- On major works of Aristotle (11701175).

- On the "Nature of the Universe" in Marrakech (1178).

- On "Incoherence of the incoherent philosophy" of alGhazali (1184).

- On Aristotle's "Metaphysics" and "On the soul” (1190).

- On Plato's “Republic” (1195)

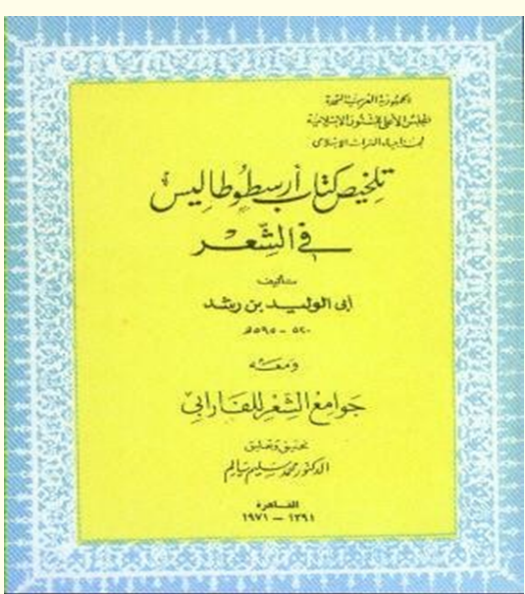

Figure 17

Abu 'Ali al-Husayn ibn 'Abd Allah ibn Sina (Avicenna) (980 1037)

- The Prince of Physicians (20 books in medicine) was born in Bukhara, Uzbakistan. He was also a scholar in mathematics, physics, philosophy and law (20 books).

- "Kitab al-Shifa" (the book of healing): a medical and philosophical encyclopedia.

- "Al-Qanun fi al-Tibb" (the canon of medicine, 1 million words): codifies all existing medical knowledge, his own observations, diet, climate, breast cancer, tumors, poisons, meningitis, diagnostic ophthalmology, 760 medicinal plants.

- In this illustration from 1320 , a lecturer reads from a book labeled Avicenum (ibn Sina) while an assistant prepares a compound with mortar and pestle (right).

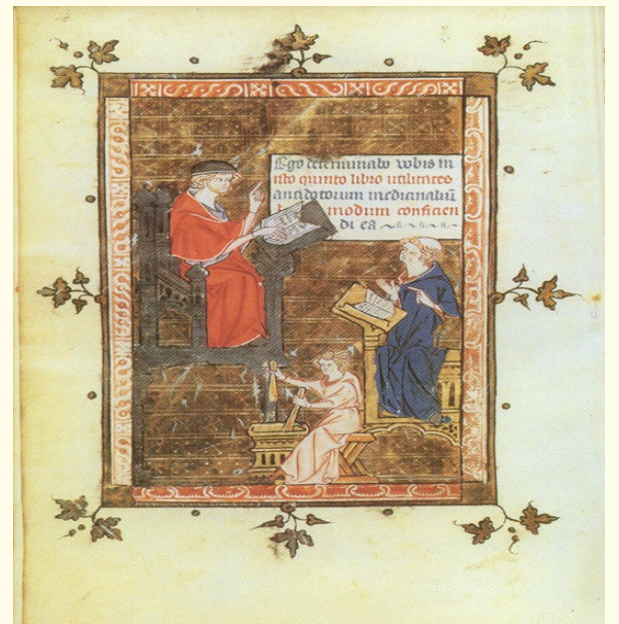

Figure 18

Ibn Sina

Ibn Sina's Canon made its first appearance in Europe by the end of the $12^{\text {th }}$ century, and its impact was dramatic. Copied and recop- 
ies, it quickly became the standard European medical reference work. It was issued in 16 editions by the end of the $15^{\text {th }}$ century; more than 20 editions in the next century. By 1537, the Canon was still a required textbook at the University of Vienna. Excerpts from a Latin translation of Verses on Medicine by Ibn Sina (right).

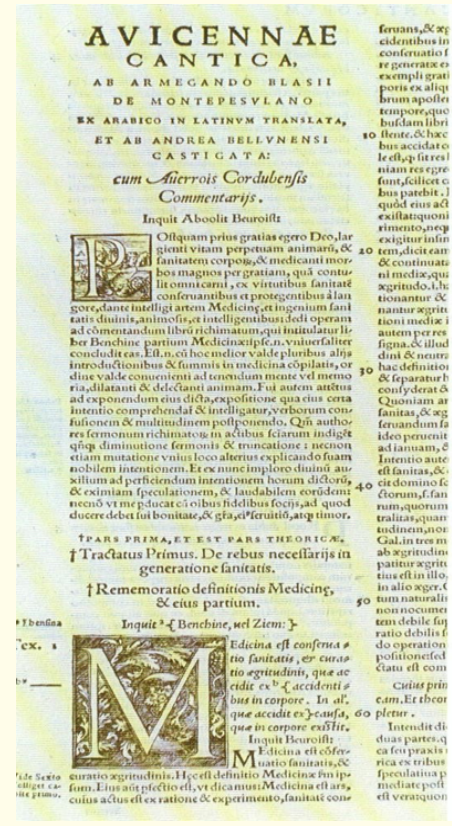

Figure 19

\section{Ibn Sina's Canon}

- This page from a $14^{\text {th }}$ century copy of Avicenna's five-volume Canon of Medicine describes several internal organs, as well as the skull and bones. The Canon was a compilation of Greek and Islamic medical knowledge.

- The title reads "Diseases of the cornea."

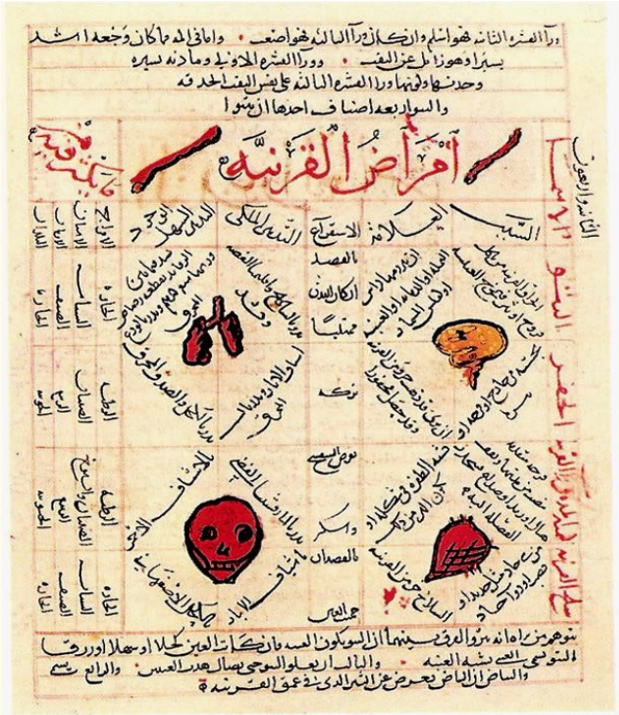

Figure 20
Ibn Sina remains a hero today His portrait decks a wall in Bukhara, Uzbekistan.

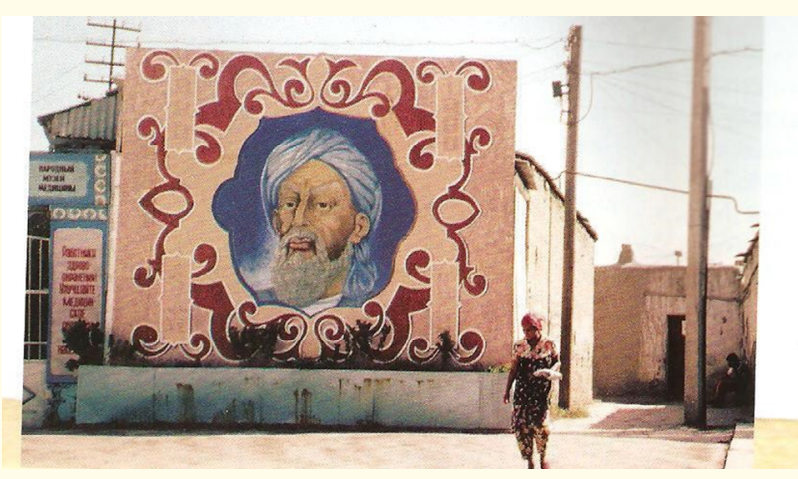

Figure 21

Surgery: (Left) In the Surgeon's Tract by Sharaf al-Din (1465) pointing to site of scalp incisions; (right) surgical instruments in this 13 century Latin translation of The Method by Abu al-Qasim, Islam's greatest medieval surgeon who practiced in 10th century Cordoba.
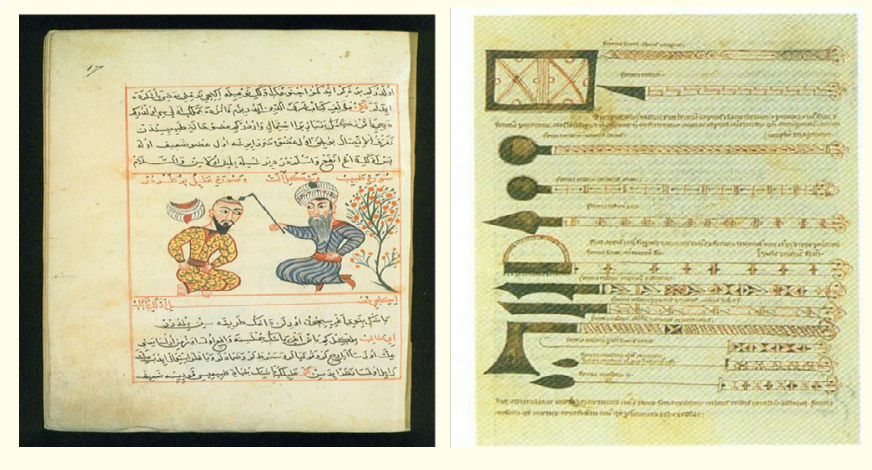

Figure 22

Ophthalmology and eye disease

Trachoma and ophthalmia were prevalent in the dusty plains of the Middle East. Arab physicians and oculists attained high levels of proficiency with considerable contributions to the science and art of ophthalmology.

- Hunyan bin Ishaq was the first to write a systematic manual on ophthalmology in 10 treatises, complete with diagrams, between 840 and 860 . This work was completed by his student and nephew Hubaysh and survived to date.

- Hunyan discussed the anatomy of the eye, brain and optic nerves, physiology, diseases and treatment of the eye.

- A diagram of the eye from one of Hunyan's 10 treaties on the eye. 


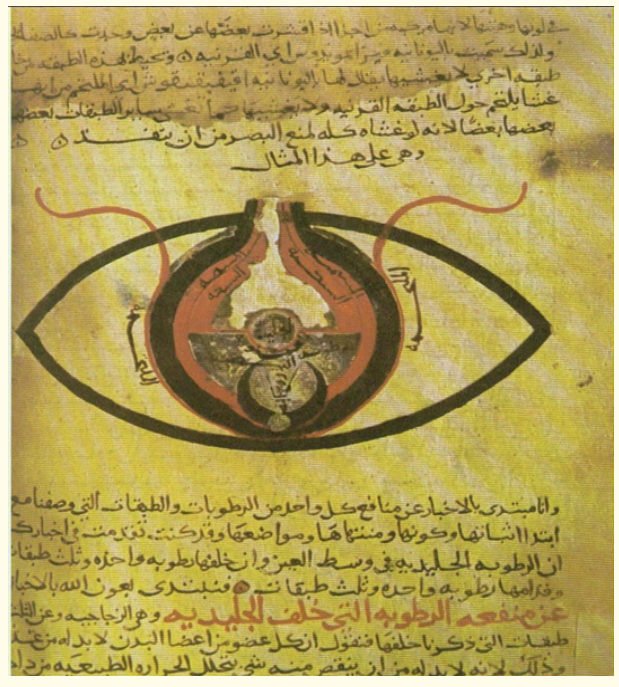

Figure 23

The peak of the art and science of ophthalmology

- Ali bin Isha: Zakhiraat al-Kahhalin (treasures for ophthalmologists in year 1000): comprehensive summary of all past achievements.

- Ammar bin 'Ali al-Mawsili (bin Isa's contemporary) was first to introduce suction and removal of cataract using a hollow needle to avoid "aqueous calamity"; a technique revived by a French doctor, Blanchet, in 1846.

- Khalifa bin Abu al-Mahasin of Aleppo completed an introduction to eye surgery and operations.

- Salah ad-Din bin Yusuf of Hamah, Syria: Nur al 'Uyun (light of the eyes, 1296) with diagrams)

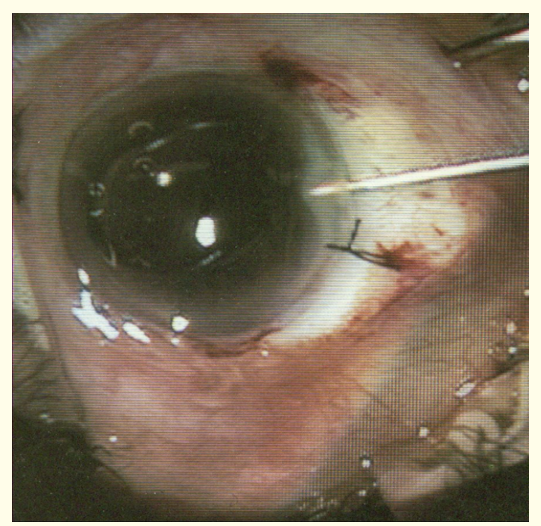

Figure 24

Pharmacy and pharmacology

- Pharmacology became a discipline independent from medicine about 800 . The first privately owned and managed pharmacies appeared in the 9th century in Baghdad; drugs and spices from Asia and Africa were readily avail- able. Pharmaceutical preparations were manufactured and distributed commercially in the marketplace. Formulas written in Arabic texts found their way in European texts influencing herbals and formularies up to modern times.

- This $15^{\text {th }}$ century Italian mural of a pharmacy was painted $>$ 600 years after the $1^{\text {st }}$ private apothecary opened in Baghdad.

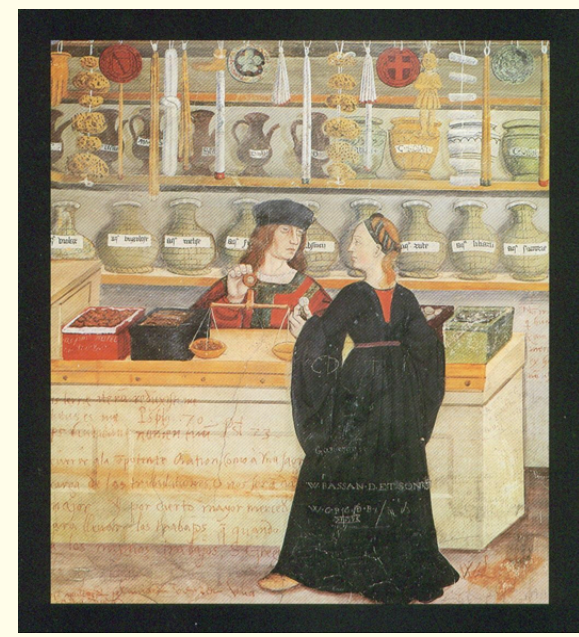

Figure 25

\section{Arab physicians and pharmacology}

Arab physicians added hundreds of medicines to those recorded by the Greeks. In this Ottoman manuscript, two doctors give instructions on the preparation of prescriptions.

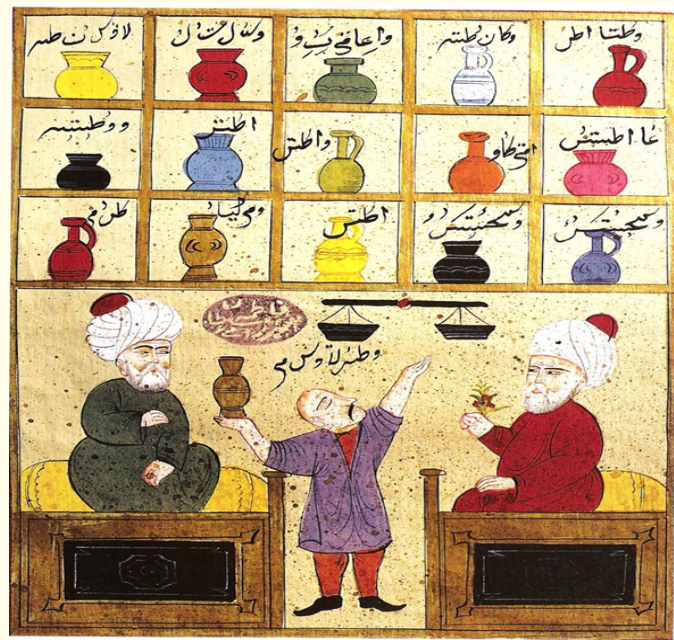

Figure 26

The book of antidotes

Nine Greek physicians are honored and portrayed in one of the opening pages of an Arabic medical manuscript written in the region of Musol, Iraq, between 1220 - 1250. The text "Antidotarium" first outlines the thoughts of the great 2 nd century Greek physician 
Galen on antidotes to snakebite, then continues with an original discussion of other antidotes, their preparation, dosage and method of use. Galen's portrait is at bottom left.

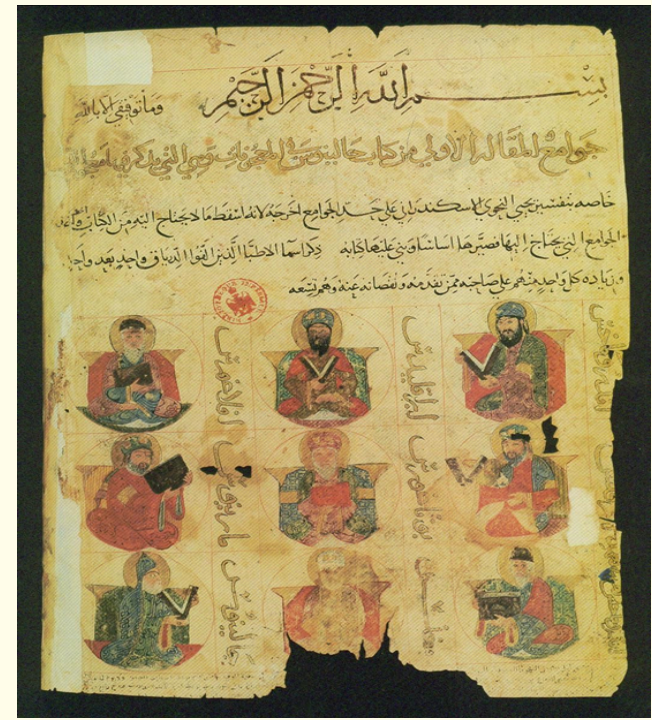

Figure 27

An illustration from the Book of Antidotes. A physicians looks on as a boy, suffering from a snakebite, cures himself by killing and eating the reptile along with some berries from the laurel tree.

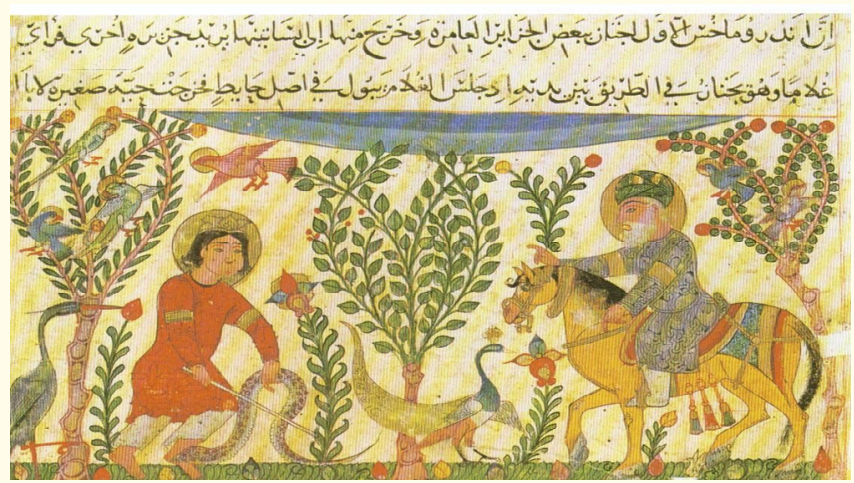

Figure 28

"De Materia Medica" by $1^{\text {st }}$ century Greek physician/pharmacologist Dioscorides describes 600 medically important plants and 1000 botanical drugs.

Dioscorides hands a plant and knowledge it represents to a student (an Ottoman ms.) (left) An autumn crocus from a copy of a 1224 Arabic translation of Materia Medica (right)

Pharmacy and famous pharmacists

- Sabur bin Sahl (died 869): author of the 1st known formulary in Islam.

- Ar-Razi: treatise on pharmacy.

- Ibn Sina (books II and V of al Qanun.
- Abu-ar-Rayhan al Biruni (died 1051): “As-Saydalah" on pharmacy and pharmacology and other branches of healing arts.

- Ibn at-Tilmidh: "Aqrabadhin" on preparations and prescriptions.
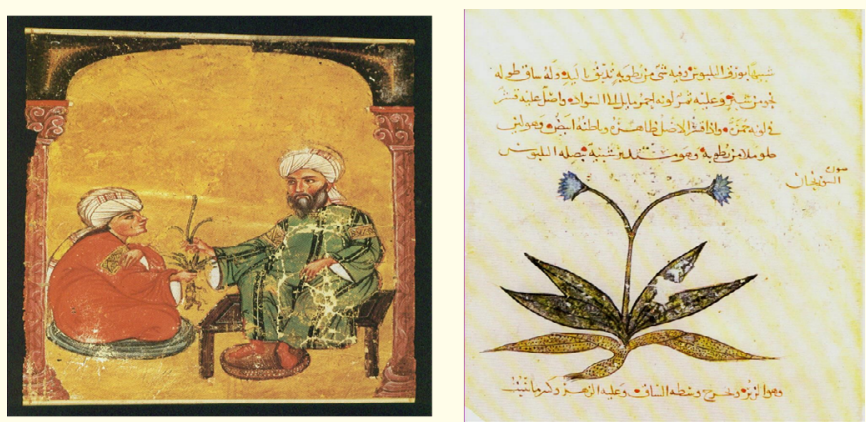

Figure 29

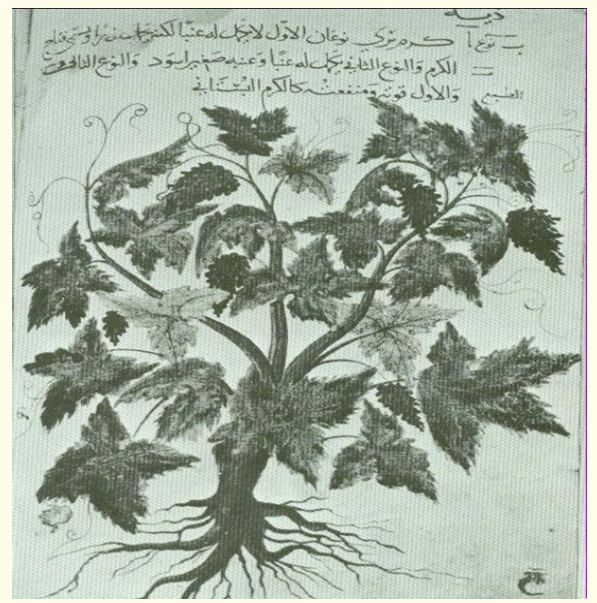

Figure 30

Wide Interest in Natural, Products, Herbology, Zoology, Experiments with Drugs, Seasons, Symptoms, Dosages, Potency, Toxins.

An illustration from a $15^{\text {th }}$ century Persian pharmaceutical manuscript (right).

\section{Hospitals and medical education}

The early Arab concept of the modern hospital, under the patronage of the Arab Caliphs, became the prototype for the development of the modern hospital for promotion of health, cure of diseases, and teaching and expanding the medical knowledge. They were endowed by state treasury. In the 10th century, hospital services were extended to meet the needs of rural areas, prisons and the "inner city." Ar-Razi and Ibn Thabit considered the hospitals as practical training facilities for health professionals and for disseminating health information.

- Mostawsaf: first aid and ER.

- Malgaa: mental and chronic cases.

- Mobile: rural and distant services.

- Prison and criminals' hospitals. 
- Military hospitals.

- Public hospitals.

Famous hospitals upkeeping the tradition of teaching hospitals

Al Adudi Hospital in Baghdad (10 ${ }^{\text {th }}$ century: with 24 doctors, lecture halls, a large library and many students from the Moslem world.

Al Nuri Hospital in Damascus.

Al Nasiri Hospital in Cairo.

Al Qymari Hospital in Damascus.

At the $10^{\text {th }}$ century Benedectine Monastery at Monte Cassino, the Middle Eastern traveler Leo Africanus translated Arab medical texts and supervised a hospital run on Arab principles. Between that time and the Renaissance, European hospitals like the one shown below, from an undated Italian manuscript, were increasingly modeled on the Arab bimaristan.

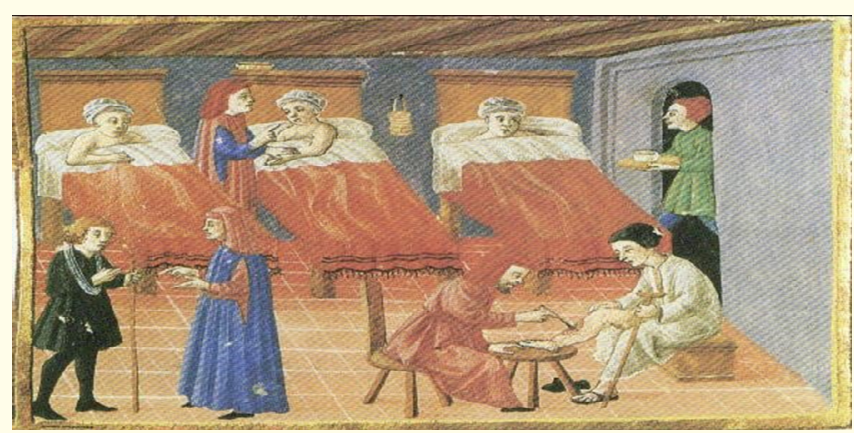

Figure 31

\section{Veterinary medicine}

- Rooted in early reliance on domesticated animals for survival in the harsh desert environment.

- Mohamed bin Akhi Hizam (860): al-Furusiyah wa al-khayl; $1^{\text {st }}$ book on horses and horsemanship.

- Al-Jahiz (died 869): al Hayawan (Book of Animals); $1^{\text {st }}$ thorough zoological study of animals.

- Abu Bakr al-Baytar of Cairo (died 1340): Kamil asSina'atayn; $1^{\text {st }}$ veterinary medicine manual.

- Kamal ad-Din ad-Damiri of Cairo (died 1405): Hayat alHayawan (life of animals); comprehensive.

- Anatomy of a horse from a $15^{\text {th }}$ manuscript; Istanbul University (right).

Abu 'Uthman 'Amr bin Bahr al-Jahiz (776 869) of Basra "Bridled Giraffe" from the Book of Animals.

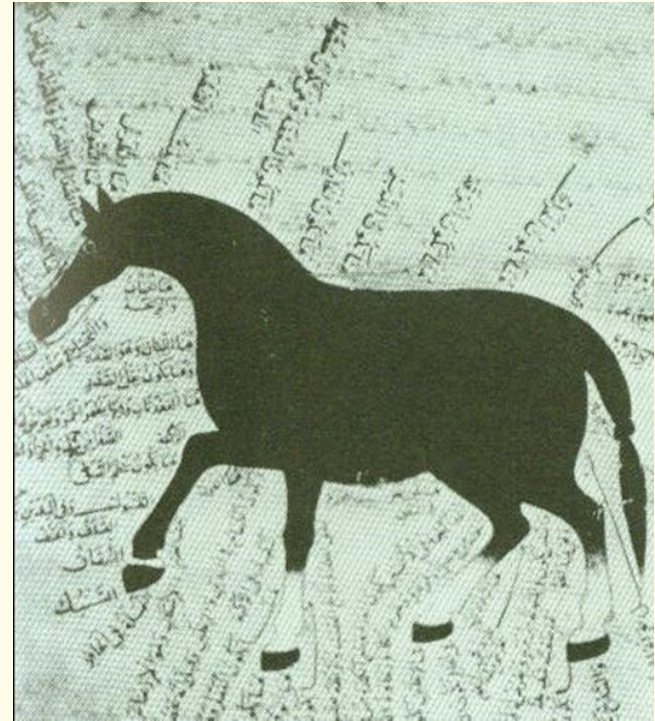

Figure 32

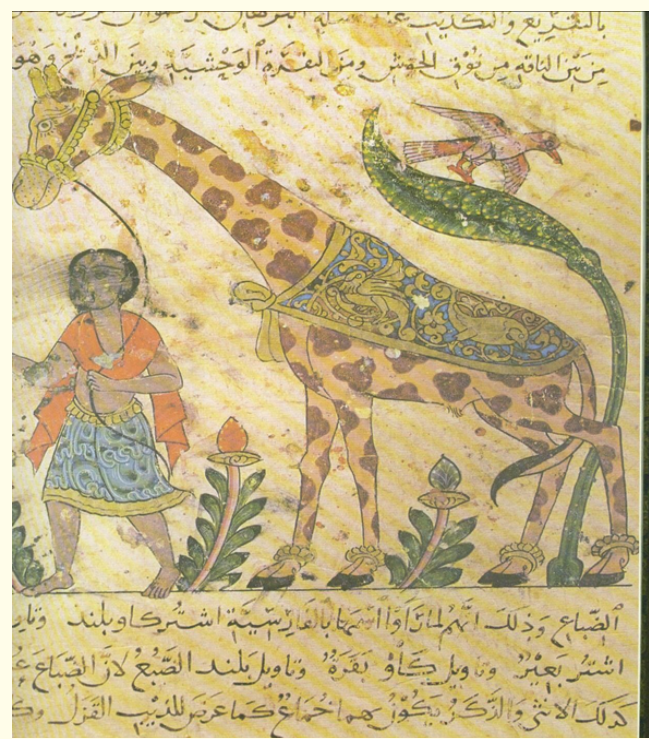

Figure 33

Illustration from Book on Veterinary Medicine A book on the care and handling of horses copied in Baghdad.

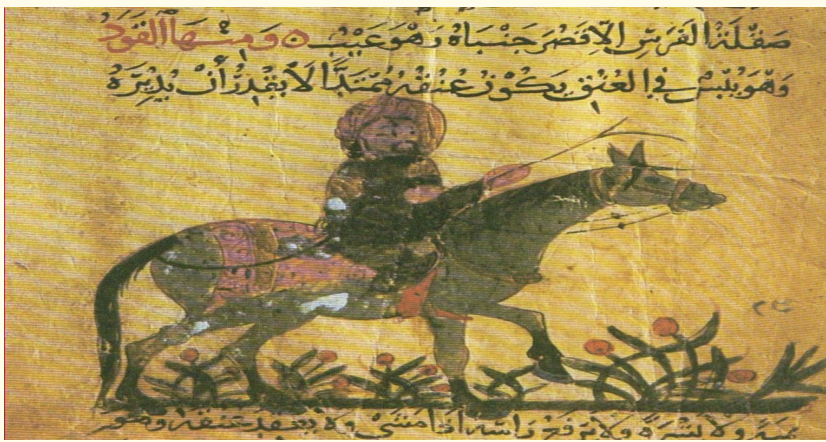

Figure 34 


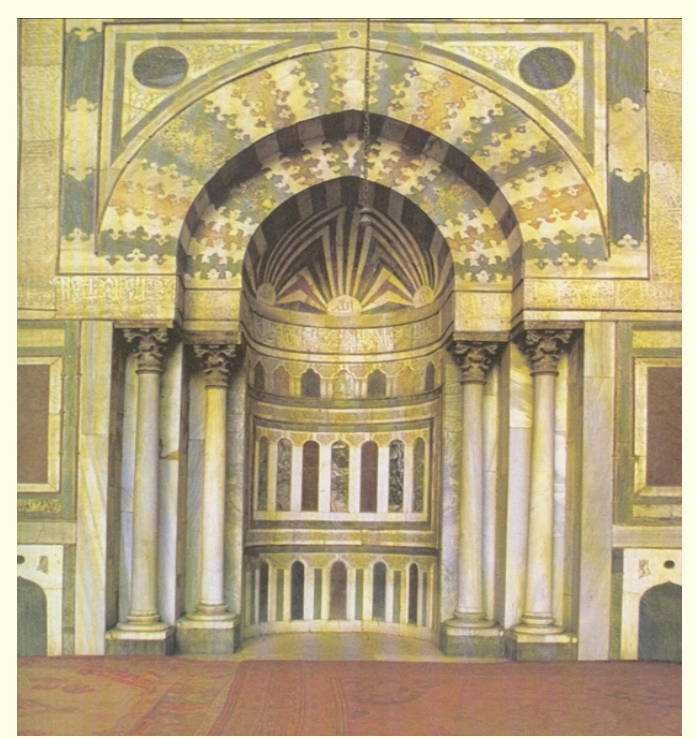

Figure 35

\section{Conclusion}

Contemporary Europeans regarded Ibn Sina and Ar-Razi as the greatest authorities on medical matters; their portraits are in the Paris School of Medicine next to Hippocrates and Galen in Dante's. The Inferno. Writings of more than 400 Arab authors deeply influenced the rebirth of European Science. They laid down the foundation of hospitals, drug trials, clinical investigation, surgery, public and dental health, ophthalmology, diet, hygiene, quarantine and infection theory that are still largely valid today.

Volume 2 Issue 10 October 2019

(c) All rights are reserved by Omar M Amin. 